\title{
A teenage girl with an untreatable nephrotic syndrome: Answers
}

\author{
Marta Cognigni $^{1}$ (D) Marco Pennesi $^{2} \cdot$ Giulia Pennesi $^{3} \cdot$ Egidio Barbi $^{1,2}$
}

Received: 19 June 2020 / Accepted: 30 June 2020 / Published online: 27 July 2020

(C) The Author(s) 2020

1. The MRI showed the presence of a mediastinal mass suggestive of a lymphoma, which was diagnosed as Hodgkin's lymphoma following a lymph node biopsy. This finding confirmed the suspicion of a paraneoplastic glomerulonephritis (PG).

Paraneoplastic glomerulonephritis is an uncommon complication of both solid and haematological malignancies, with glomerular lesions induced by products from tumour cells rather than being directly related to tumour invasion or metastasis [1]. Though PG is quite rare, particularly in childhood and adolescence, it still may be quite easily mistaken for idiopathic glomerulonephritis due to the delayed diagnosis of malignancy. About $11 \%$ of adult patients with glomerulopathies, generally presenting as nephrotic syndrome (NS), have cancer and in two-thirds of the cases, NS precedes the diagnosis of malignancy [2]. This case exemplifies one of the various glomerular lesions that can occur in different forms of PG. The link between haematological malignancies and NS is mostly observed in Hodgkin's lymphoma. The incidence of this association is $0.4 \%$ in the adult population [3], while it is not well known in childhood: two small series described an incidence rate between 0.6 and $1 \%[4,5]$. The most frequent observed renal lesion associated with Hodgkin's lymphoma is minimal change disease (1\%), while the occurrence of FSGS is much rarer [6]. According to this study [7], PG usually does not run parallel to the course of the malignancy as it usually appears before the cancer is diagnosed. This clinical observation has also been confirmed in

This refers to the article that can be found at http://dx.doi.org/10.1007/ s00467-020-04706-0

Marta Cognigni

martacognigni@gmail.com

1 University of Trieste, Trieste, Italy

2 Institute for Maternal and Child Health-IRCCS Burlo Garofolo, Trieste, Italy

3 Edinburgh Napier University, Edinburgh, UK childhood [4]. The majority of patients with PG secondary to lymphoid malignancies showed systemic symptoms (fever, weight loss, arthralgia) and high inflammatory laboratory parameters (CRP, ESR, fibrinogen), indicating that these findings should be used as red flags to promptly recognise an atypical NS. PG can also occur in solid tumours, although its incidence and prevalence in association with solid malignancies remain unclear and the causal link is still unknown. The most common solid tumour-associated glomerulopathies are carcinoma of the lung and of the gastrointestinal tract, usually associated with membranous nephropathy [8].

2. Paraneoplastic glomerulonephritis needs to be distinguished from idiopathic kidney disease. The recognition of PG before the detection of malignancy requires a high index of suspicion and needs to be included in the differential diagnosis of secondary NS, even in children and adolescents. A work-up for malignancy should be considered in all patients presenting an apparently idiopathic NS showing a poor response to steroid or immunosuppressive therapy. An atypical age of onset, the presence of systemic symptoms (persistent fever, arthralgia), persistent positive acute reactant phase laboratory tests and persistent proteinuria without other features of NS should further strengthen the suspicion of an occult lymphoma $[6,7]$.

3. The effective treatment of the tumour is reported to result in the remission of the NS without the need for a specific therapy directed at the kidney lesion [4]. Hence, the prognosis of these patients is good, with NS disappearing after cancer treatment. Remarkably proteinuria often reappears in association with eventual relapses of malignancy [9] and could therefore be the first sign of the tumour's recurrence. Cancers associated with NS are reported to have a worse prognosis in the adult population. The 1-year mortality rate in cancer patients with preexisting NS is higher than in cancer patients without prior NS, particularly, in those with haematological malignancies [10]. 


\section{Patient outcome}

The remission of NS was attained within 3 months after the initiation of chemotherapy. During the last 4 years of followup, proteinuria did not relapse and neither did the lymphoma.

\section{Discussion}

Paraneoplastic glomerulonephritis is a rare occurrence in children with solid and haematological tumours. Prolonged proteinuria, an atypical age-onset for minimal change disease, ineffective steroid, and/or immunosuppressive therapy, presence of systemic symptoms, and persistence of laboratory alterations should all suggest a paraneoplastic syndrome. Adequate and effective treatment of the tumour will result in remission of the NS. Even if the diagnosis of PG does not run parallel to the tumour, the reappearance of NS correlates directly with the tumour's relapse. For this reason, the monitoring of proteinuria becomes relevant to ensure early detection of malignancy recurrence.

Funding Information Open access funding provided by Università degli Studi di Trieste within the CRUI-CARE Agreement.

\section{Compliance with ethical standards}

Conflict of interest The authors declare that they have no conflict of interest.

Open Access This article is licensed under a Creative Commons Attribution 4.0 International License, which permits use, sharing, adaptation, distribution and reproduction in any medium or format, as long as you give appropriate credit to the original author(s) and the source, provide a link to the Creative Commons licence, and indicate if changes were made. The images or other third party material in this article are included in the article's Creative Commons licence, unless indicated otherwise in a credit line to the material. If material is not included in the article's Creative Commons licence and your intended use is not permitted by statutory regulation or exceeds the permitted use, you will need to obtain permission directly from the copyright holder. To view a copy of this licence, visit http://creativecommons.org/licenses/by/4.0/.

\section{References}

1. Ronco PM (1999) Paraneoplastic glomerulopathies: new insights into an old entity. Kidney Int 56:355-377

2. Lee JC, Yamauchi H, Hopper J Jr (1966) The association of cancer and the nephrotic syndrome. Ann Intern Med 64:42-51

3. Alpers CE, Cotran RS (1986) Neoplasia and glomerular injury. Kidney Int 30:465-473

4. Stéphan JL, Deschênes G, Pérel Y, Bader-Meunier B, BrunatMentigny M, Lejars O, Lamagnères JP (1997) Nephrotic syndrome and Hodgkin disease in children: a report of five cases. Eur J Pediatr 156:239-242

5. Büyükpamukçu M, Hazar V, Tinaztepe K, Bakkaloğlu A, Akyüz C, Kutluk T (2000) Hodgkin's disease and renal paraneoplastic syndromes in childhood. Turk J Pediatr 42:109-114

6. Mallouk A, Pham PT, Pham PC (2006) Concurrent FSGS and Hodgkin's lymphoma: case report and literature review on the link between nephrotic glomerulopathies and haematological malignancies. Clin Exp Nephrol 10:284-289

7. Audard V, Larousserie F, Grimbert P, Abtahi M, Sotto JJ, Delmer A, Boue F, Nochy D, Brousse N, Delarue R, Remy P, Ronco P, Sahali D, Lang P, Hermine O (2006) Minimal change neprotic syndrome and classical Hodgkin's lymphoma: report of 21 cases and review of the literature. Kidney Int 69:2251-2260

8. Lien YH, Lai LW (2011) Pathogenesis, diagnosis and management of paraneoplastic glomerulonephritis. Nat Rev Nephrol 7(2):85-95

9. Bacchetta J, Juillard L, Cochat P, Droz JP (2009) Paraneoplastic glomerular disease and malignancies. Crit Rev Oncol Hematol 70: $39-58$

10. Christiansen CF, Onega T, Sværke C, Körmendiné Farkas D, Jespersen B, Baron JA, Sørensen HT (2014) Risk and prognosis of cancer in patients with Nephrotic syndrome. Am J Med 127: 871-877

Publisher's note Springer Nature remains neutral with regard to jurisdictional claims in published maps and institutional affiliations. 